Plant Tissue Cult. \& Biotech. 24(1): 27-36, 2014 (June)

$\overline{\text { PTC\&B }}$

\title{
In vitro Development of Cauliflower Synthetic Seeds and Development of Plantlets In vivo
}

\section{Zahida Qamar, Md. Belal Hossain*1, Idrees A. Nasir, Bushra Tabassum and Tayyab Husnain}

National Centre of Excellence in Molecular Biology, University of the Punjab, 87-West Canal Bank Road Thokar Niaz Baig, Lahore-53700, Pakistan

Key words: Cauliflower, Hypocotyl, Synthetic seeds, Encapsulation

\begin{abstract}
Synthetic seeds of cauliflower cv. Chillout were developed by encapsulating mature somatic embryos in neutral gel media. Somatic embryos were obtained by optimizing callus and cell suspension cultures of cauliflower. Friable, yellowish embryogenic calli were obtained on MS supplemented with $2 \mathrm{mg} / \mathrm{l}$ 2,4-D and $0.5 \mathrm{mg} / \mathrm{l} \mathrm{BAP} \mathrm{using} \mathrm{hypocotyl} \mathrm{as} \mathrm{explants,} \mathrm{while} \mathrm{calli} \mathrm{were} \mathrm{regenerated}$ in media consisting of $5 \mathrm{mg} / \mathrm{l} \mathrm{BAP,} 2 \mathrm{mg} / \mathrm{l} \mathrm{Kn}$ and $6 \mathrm{mg} / \mathrm{l} \mathrm{GA}$. Somatic embryogenesis was induced in cell suspension culture where auxins were removed in successive steps triggering conversion of globular cells into the heart, torpedo stage $(71 \%)$ and finally into cotyledonary/somatic embryos $(28 \%)$. The mature somatic embryos were encapsulated by mixing mature cell suspension with sodium alginate and calcium chloride mixture (1:4). Developed synthetic seeds germinated into complete plantlets when placed in neutral gel media. Germination efficiency of synthetic seeds decreased to about 50 per cent after 12 weeks of storage at $4^{\circ} \mathrm{C}$ followed by a rapid decrease to zero per cent after 16 weeks. It was also observed that cauliflower plantlets from synthetic seeds survived successfully when transferred to soil demonstrating that cauliflower synthetic seeds is a promising step towards their in vivo direct use.
\end{abstract}

\section{Introduction}

Cauliflower (Brassica oleracea var. botrytis) belonging to Brassicaceae is one of the most cultivated vegetables in the world. In addition, it has also been recently found to be useful in the prevention of cancer. The growers are facing several problems in the production of a uniform and quality crop of cauliflower. One of

*Author for correspondence: <mbhossainsau@yahoo.com>. ${ }^{1}$ Present address: Department of Plant Pathology, Sher-e-Bangla Agricultural University, Dhaka-1207, Bangladesh. 
the major problems in cauliflower cultivation is the quality seeds production. Cauliflower is an open pollinated crop and there are technical challenges to producing a reliable self incompatible inbred lines. So, there is a strong demand for improved seed biotechnology resulting in efficient and stable regeneration methodology. An effective protocol was designed for the production of suitable cauliflower propagules from fractionated and graded curd. These propagules were considered suitable for encapsulation in sodium alginate for synthetic seed production (Kieffer et al. 2001). The use of micro shoots has been reported to be successful for the production of synthetic seeds in a variety of plant species viz. Picrorhiza kurrooa (Mishra et al. 2010).

The major objective of this present study was to establish an efficient callus induction protocol from hypocotyls for cell suspension to produce cauliflower synthetic seeds. The assessment of germination viability of synthetic seeds and the establishment of plantlets from synthetic seeds in vivo was another aim of this study.

\section{Materials and Methods}

Cauliflower seeds of cv. Chillout were placed on a sterile moist filter paper in Petri plates and incubated in the dark at $25 \pm 2{ }^{\circ} \mathrm{C}$ for germination. Before plating, seeds were surface sterilized with $0.1 \%$ mercuric chloride solution for $5 \mathrm{~min}$ followed by washing with sterile distilled water three times, 5 min each under aseptic condition. The hypocotyl explants from 5 - 7 days old seedlings were used for callus formation. The hypocotyls were cut into $0.3-0.6 \mathrm{~cm}$ long pieces and placed horizontally in callus induction MS supplemented with $2 \mathrm{mg} / 1$ 2,4-D, $0.5 \mathrm{mg} / \mathrm{l} \mathrm{BAP,} 3 \%$ sucrose and solidified with phytagel; the $\mathrm{pH}$ of the medium was adjusted at 5.7 - 5.8 before autoclaving. Pro-embryogenic callus was obtained approximately after 15 days with regular sub-culturing at 7 days interval. Initially the cultures were maintained in the dark for 3 - 5 days and subsequently placed under $16 / 8 \mathrm{hrs}$ photoperiod.

To check the shoot regeneration response of cauliflower, the established embryogenic calli were placed in various shoot regeneration media, each supplemented with different hormonal supplements. The best combination of regeneration media was 4 - $6 \mathrm{mg} / \mathrm{l} \mathrm{BAP,} 2$ - $4 \mathrm{mg} / \mathrm{l} \mathrm{Kn}$ and 4 - $6 \mathrm{mg} / \mathrm{l} \mathrm{GA} 3$ fortified with MS vitamins $(30 \mu \mathrm{M}$ adenine sulphate, $3 \mu \mathrm{M}$ thiamine $\mathrm{HCl}$ and $580 \mu \mathrm{M}$ $\mathrm{NaH}_{2} \mathrm{PO}_{4}$ ).

The cell suspension of the embryogenic callus was established in the callus medium initially for one week, followed by subculturing it in the same medium without 2,4-D. For this purpose, 250 - $300 \mathrm{mg}$ of calli were placed in $30 \mathrm{ml}$ of cell suspension media and placed on a rotary shaker at $90 \mathrm{rpm}$ under $16 \mathrm{hrs}$ 
photoperiod at $22 \pm 2{ }^{\circ} \mathrm{C}$. Cells were regularly observed under the microscope (Olympus U-PMTVC 3B15937, Japan). For synchronization to achieve uniform cell suspension and to remove dead cell clumps, cells were sieved through a stainless sieve of $150 \mu \mathrm{m}$ pore size mesh. Further, the cell suspension containing mature torpedo shaped somatic embryos were used for synthetic seed formation. The cell suspension containing embryos and sodium alginate solution $(3 \%, \mathrm{w} / \mathrm{v})$ was mixed in the ratio of $1: 4$, and the mixture was dispensed into $100 \mathrm{mM}$ calcium chloride solution $\left(\mathrm{CaCl}_{2} \cdot 2 \mathrm{H}_{2} \mathrm{O}\right)$. Beads formation started as soon as the drops of sodium alginate fell into the calcium chloride solution placed on a magnetic stirrer. After half an hour, beads were removed from the calcium chloride solution followed by the coating of regeneration media and washed with Radomil Gold solution (fungicide) @ 0.25\%. After half an hour beads were collected through filtration.

Synthetic seeds were stored at $4^{\circ} \mathrm{C}$. Their germination viability was checked after 16 weeks of their storage. For germination assessment, neutral gel consisting phytagel dissolved in autoclaved tap water was used. Complete plantlets regenerated from synthetic seeds were transferred into pot containing autoclaved compost soil under controlled conditions. The compost soil was prepared by thoroughly mixing clay, sand and compost in the ratio of $1: 1: 1$ respectively. The plants were completely covered with plastic bag for 2 weeks to maintain the humidity and then progressively exposed to normal environmental conditions for acclimation.

\section{Results and Discussion}

Calli were developed from hypocotyls in MS containing 2,4-D and BAP. The embryogenic callus was identified by their anatomical features such as yellowish color, small globular but densely filled cytoplasmic cells. It was observed that a suitable concentration of BAP and 2,4-D is required for the induction of friable, nodular, yellowish embryogenic callus (Aly et al. 2002, Ma and $\mathrm{Xu} \mathrm{2002,}$ Hernandez et al. 2003, Nath and Bugagohain 2005). Cauliflower embryogenic callus and somatic embryo induction showed auxin - and cytokinin dependent response. The study revealed that the requirement of in vitro regeneration may vary from cultivar to cultivar (Sonia et al. 2010). In another study, it was observed that 2,4-D in combination with cytokinin (BAP), are two essential plant growth regulators for the induction of embryogenic callus and somatic embryos (Chalupa et al. 1990, Maureen et al. 1990, Haider et al. 1993, Kim et al. 2003). The influence of different concentrations of sucrose such as $20 \mathrm{~g}$, $30 \mathrm{~g}$, and $40 \mathrm{~g}$ per liter of media was also observed to influence the embryogenic potential of callus. In this study, $30 \mathrm{~g}$ sucrose was found to be the best for embryogenic callus 
induction. These results were similar to those reported by Ganesan et al. (2007) in okra and in black iris by Shibli and Ajlouni (2000). For successful regeneration of synthetic seeds from the somatic embryos, good quality embryogenic callus is essential (Ganesan and Jayabalan 2004).

To observe the shoot regeneration response of embryogenic calli, different media were tested. In the present investigation, it was observed that the treatment of $2 \mathrm{mg} / \mathrm{l} \mathrm{Kn}, 6 \mathrm{mg} / \mathrm{l} \mathrm{GA} 3$ combined with $5 \mathrm{mg} / \mathrm{l} \mathrm{BAP}$ and MS vitamin, gave the optimal regeneration results from the callus in terms of the number of growing shoots as depicted in Fig. 1 and 1a. Therefore, this combination is recommended for enhanced regeneration in cauliflower cv Chillout. Cytokinin concentrations have a central role associated with sink activity and nutrient partitioning (Kuiper 1988, Kuiper et al. 1989).
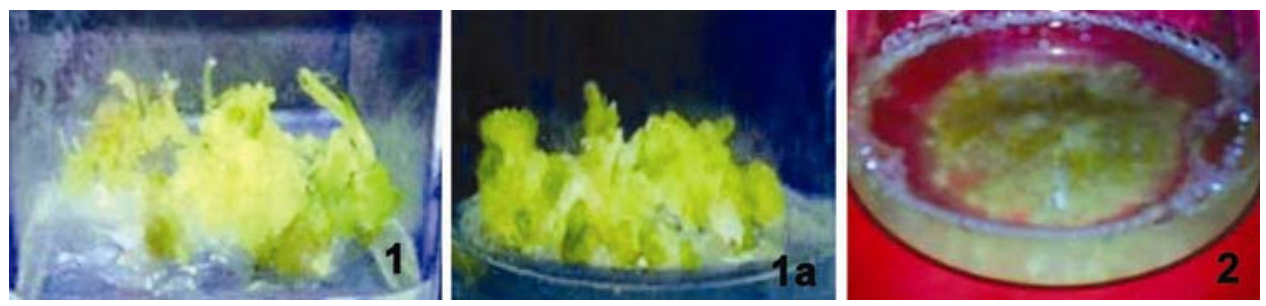

Figs 1-2. Shoot regeneration from embryogenic callus $(1,1 \mathrm{a})$ and cell suspention cultures

(2) of Cauliflower cv. Chillout.

After the optimization of callus induction and shoot regeneration from callus, cell suspension was made in the same medium devoid of 2,4-D. The fresh established cell suspension was morphologically heterogeneous as shown in Fig. 2. Under the microscope, two types of cells were observed. The type-I cells were elongated in shape, vacuolated and larger in size without starch contents. Such cells were few in number (10 - 15\%). They were discarded by sieving through $150 \mu \mathrm{m}$ mesh. The type-II cells were globular, round in shape and smaller in size characterized by dense cytoplasm, nucleolus like bodies with rich starch grains and plastids. The type of such cells were found up to 85 - 90 per cent of the total viable cells. Both types of cells were clearly seen under the microscope (Fig. 3a \& b). A similar type of cell morphology in suspension culture was reported in carrot by Fujii et al. (1989). In the present study, it was also observed that in the cell suspension cultures, the suspended cells of cauliflower passed through different stages of embryogenesis. The initial normal globular cells developed into heart-, torpedo- and cotyledonary shaped embryogenic cells. If the cell suspension cultures were sieved at a longer interval than normal duration of 7 days, the percentage of the non-embryogenic elongated cells increased 
dramatically. These results are similar to those reported in cucumber cell suspension cultures (Tabassum et al. 2010).

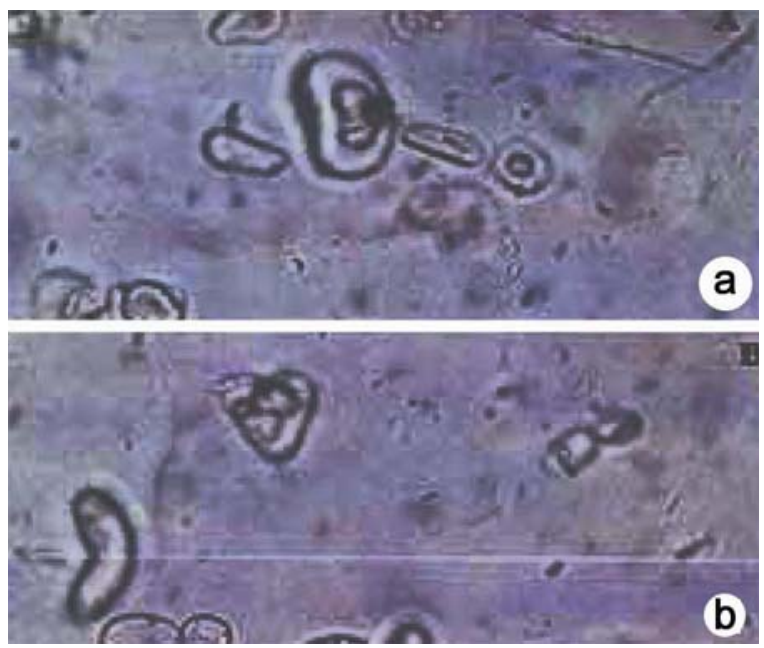

Fig. 3. Microscopic views of the suspended cells in suspension culture. (a) Two types of cells were clearly visible (i) elongated in shape vacuolated and larger in size, (ii) round in shape and smaller in size, dense cytoplasm, apparent nucleolus. (b) Globular cells turned into heart or angular shaped.

The suspended cells were synchronized according to the procedure reported by Giuliano et al. (1983). After two to three successive subculturing at weekly intervals, 84 per cent of the cells were found at the globular stage; thereafter they were transferred to modified suspension media containing BAP only. After 2 - 3 days, based on microscopic studies, 71 per cent of the total cells successfully turned into heart- and torpedo-shaped embryos. Subsequent subculturing on MS supplemented with BAP and NAA, led to uniform maturation of only 28 per cent somatic embryos (Fig. 4). The values obtained were found highly significant as revealed by ANOVA (Table 1). After synchronization, the mature somatic embryos were coated by using sodium alginate. Mature cell suspension and sodium alginate (ratio $1: 4$ ) were dropped into $100 \mathrm{mM}$ calcium chloride solution to form synthetic seeds. For hardening, these synthetic seeds were rinsed in double distilled water, followed by immersing the seeds in MS- containing 3\% sucrose, MS fortified with $5 \mathrm{mg} / \mathrm{l} \mathrm{BAP,} 2 \mathrm{mg} / \mathrm{l} \mathrm{Kn}$ and $6 \mathrm{mg} / \mathrm{l} \mathrm{GA} 3$ and MS vitamin. Thereafter, the seeds were incubated at gyratory shaker for $30-40 \mathrm{~min}$. After incubation, mature embryos turned into complete seed structures as shown in Fig. 5. It is reported that sodium alginate complex with calcium chloride is most suitable for encapsulation because of viscosity, low toxicity and quick 
gelatinization (Redenbaugh et al. 1993). It is also reported that in carrot 2 per cent sodium alginate solution with $75 \mathrm{mM}$ calcium chloride is the best for coating the somatic embryos to form synthetic seeds (Latif et al. 2007).

Table 1. Showing the results of ANOVA.

\begin{tabular}{lccccc}
\hline \multicolumn{5}{c}{ No. of cells } & \\
\hline & Sum of squares & df & Mean square & F & Sig. \\
\hline Between groups & 4604.667 & 2 & 2302.333 & 56.307 & 0.000 \\
Within groups & 245.333 & 6 & 40.889 & & \\
Total & 4850.000 & 8 & & & \\
\hline
\end{tabular}

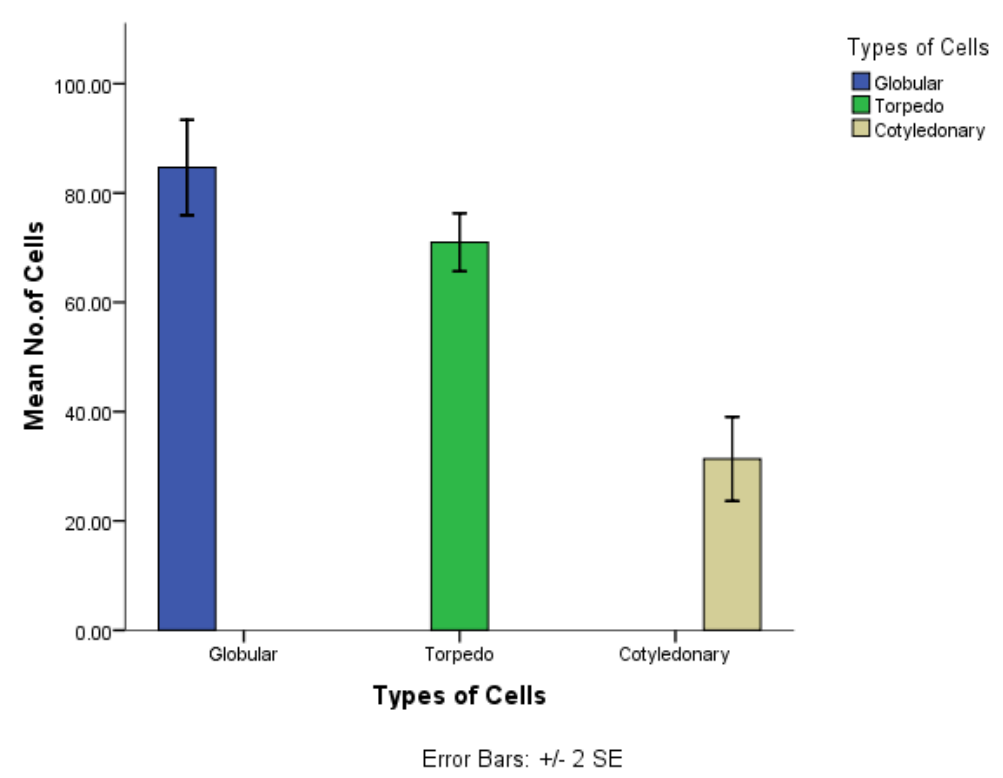

Fig. 4. Conversion of globular shaped cells to heart- and finally into cotyledonary- cells in cell suspension culture. Values were found significant as revealed by ANOVA.

The germination percentage of cauliflower synthetic seeds was found to be 83.5. It was also observed that the germination efficiency was considerably decreased with the increase of storage time as shown in Fig. 6. The germination efficiency was reduced almost to 50 per cent after 12 weeks of storage but as the storage time was prolonged to the 16th week, the rate of germination percentage was zero. Yussof et al. (2011) used encapsulation technique for production of broccoli synthetic seeds (Brassica oleracea) with sodium alginate and observed that 70 per cent germination of synthetic seeds. In our study, synthetic seeds 
were germinated in neutral gel (Fig. 7), while encapsulations of synthetic seeds were done with nutrient mixture; calcium alginate was used to protect the synthetic seeds from microbial infections and mechanical damages during handling. Thus it showed that somatic embryo encapsulation is one of the promising methods for sowing embryos and regeneration of cauliflower into plantlets.

Shoot and root formation was observed when germinated synthetic seeds were transferred from the Petri plate to test tube containing shoot and root regeneration media. In this study, we used three different regeneration media for shoot formation and among the three combinations, excellent performance was obtained in the third combination followed by the second and the first one. The best root formation was also observed in the third combination containing 1.0 mg/l NAA in addition (Fig. 8). A similar observation was reported in broccoli regeneration from synthetic seeds (Yussof et al. 2011). In their study, George et al. (2008) reported plant propagation by means of tissue culture. They recommended multiple shoot formation in higher concentration of BAP and lower concentration of IAA.

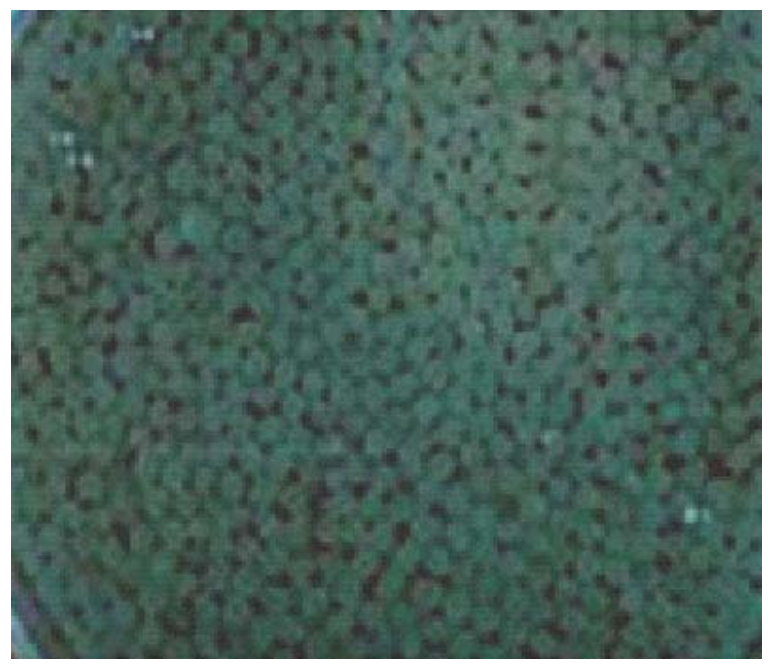

Fig. 5. Cauliflower synthetic seeds.

After regeneration in a controlled environment, the developing plantlets were transferred into pots containing autoclaved compost soil. The optimal conversion rate and viability were obtained in $1: 1: 1$ of clay, sand and compost, respectively (Fig. 9). In several earlier studies researchers investigated the possibility of sowing synthetic/artificial seeds in soil, for example, using vermiculite, sand and soil for M.26 apple rootstock (Micheli et al. 2002) and 
Citrus reticulata (Antonietta et al. 2007) and the use of sand for elite indica rice (Roy and Mandal 2008). It needs to be emphasized that the optimal conditions need to be determined empirically for each species examined.

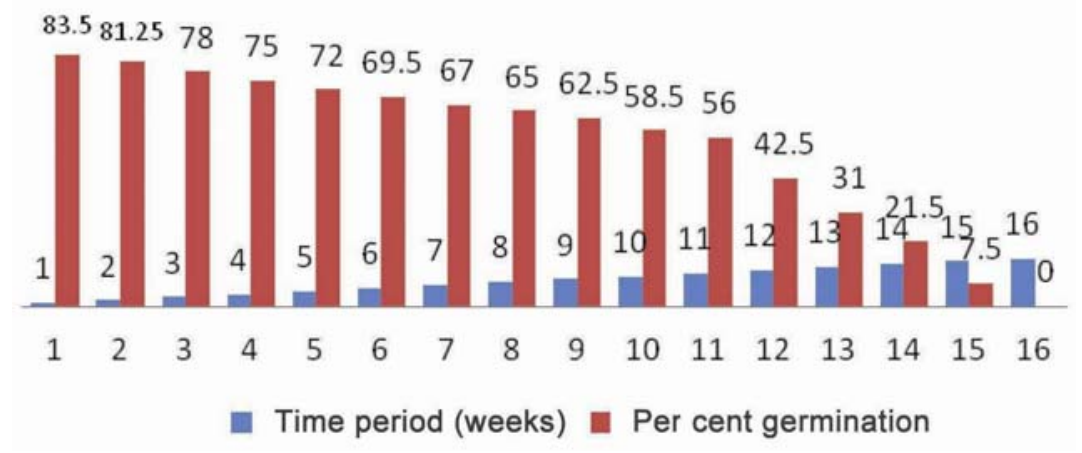

Fig. 6. Germination viability percentage of cauliflower synthetic seeds developed by encapsulating mature somatic embryos by sodium alginate.
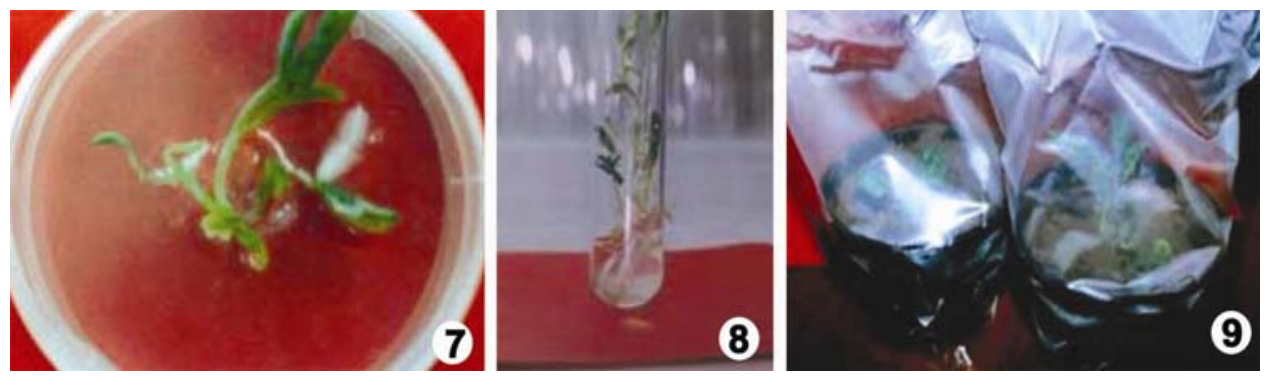

Figs 7 - 9. 7. Cauliflower synthetic seeds germinated on neutral gel media. 8. Cauliflower plantlets with regenerated shoots and roots derived from synthetic seeds. 9. Complete cauliflower plantlets derived from synthetic seeds.

This is the first successful study of cauliflower synthetic seed production from the hypocotyl, successful germination and regeneration of synthetic seeds into complete plantlets. The main objective of the present study was to optimize an inexpensive and yet a sophisticated method for synthetic seed production of cauliflower with a prolonged period of viability capable of germinating and developing into viable plants. Synthetic seed technology seems to be a promising method in plant tissue culture industry. This method is very advantageous, especially for those plant species which do not produce seeds or for a long term storage of elite genotypes selected through traditional breeding methods or genetically engineered plants. 


\section{References}

Aly MAM, Rathinasabapathi B and Kelley K (2002) Somatic embryogenesis in perennial statice Limonium ellidifolium, Plumbaginaceae. Plant Cell Tiss. Organ Cult. 68: 127-135.

Antonietta G, Ahmad H, Maurizio M and Alvaro S (2007) Preliminary research on conversion of encapsulated somatic embryos of Citrus reticulata Blanco, cv. Mandarino Tardivo di Ciaculli. Plant Cell Tiss. Organ Cult. 88(1):117-120.

Chalupa V, Malá J and Dujíčková M (1990) Somatic embryogenesis and regeneration of spruce (Picea abies /L./Karst.) and oak (Quercus robur L.). In: Manipulation in vitro in higher plants, Proc. Conf. Inst. Exp. Botany, Prague, CSAS, Olomouc, CR: p 98.

Fujii J, Slade D and Redenbaugh K (1989) Maturation and greenhouse planting of alfalfa artificial seeds. In Vitro Cell Dev Bio Plant 25(12): 1179-1182.

Ganesan, M and Jayabalan N (2004) Evaluation of hemoglobin (erythrogen) : for improved somatic embryogenesis and plant regeneration in cotton (Gossypium hirsutum L. cv. SVPR 2). Plant Cell Reports 23: 181-187.

Ganesan M, Chandrasekar R, Kumari B and Jayabalan N (2007) Somatic embryogenesis and plant regeneration of Abelmoschus esculentus through suspension culture 51(3): 414-420.

George EF, Hall MA and Klerk GJD (2008) In: The Background ( ${ }^{\text {rd }}$ eds), Plant propagation by tissue culture. Springer, Dordrecht, London.

Giuliano GD, Rosellini D and Terzi M (1983) A new method for the purification of the different stages of carrot embryoids. Plant Cell Tiss. Org. Cult. 17: 191-218.

Haider SA, Islam R, Kamal AHM, Rahman SM and Joarder OI (1993) Direct and indirect organogenesis in cultured hypocotyl explants of Abelmoschus esculentus L. Moench. Plant Tissue Cult. 3(2): 85-89.

Hernandez L, Celestino C and Toribio M (2003) Vegetative propagation of Quercus suber L. by somatic embryogenesis. Plant Cell Reports 21: 759-764.

Kieffer M, Simkins N, Fuller MP and Jellings AJ (2001) A cost effective protocol for in vitro mass propagation of cauliflower. Plant Sci. 160(5): 1015-1024.

Kim SW, Kim TJ and Liu JR (2003) High frequency somatic embryogenesis and plant regeneration in petiole and leaf explant cultures and petiole-derived embryogenic cell suspension cultures of Hylomecon vernalis. Plant Cell Tiss. Org. Cult. 74: 163-167.

Kuiper D (1988) Growth Responses of Plantago major L. ssp. pleiosperma (Pilger) to changes in mineral supply: evidence for regulation by cytokinins. Plant Physiol. 87(3): 555-557.

Kuiper D, Kuiper PJC, Lambers H, Schuit J and Staal M (1989) Cytokinin concentration in relation to mineral nutrition and benzyladenine treatment in Plantago major ssp. pleiosperma. Physiol. Plant. 75(4): 511-517.

Latif Z, Nasir IA and Riazuddin S (2007) Indigenous production of synthetic seeds in Daucus carota. Pak. J. Bot. 39(3): 849-855.

Ma G and Xu Q (2002) Induction of somatic embryogenesis and adventitious shoots from immature leaves of cassava. Plant Cell Tiss. Org. Cult. 70: 281-288.

Maureen M, Fitch M and Manshardt M (1990) Somatic embryogenesis and plant regeneration from immature zygotic embryos of papaya (Carica papaya L.). Plant Cell Reports 9: 320-324. 
Micheli M, Pellegrino S, Piccioni E and Standardi A (2002) Effects of double encapsulation and coating on synthetic seed conversion in M.26 apple rootstock. J. Microencapsul. 19: 34-356.

Mishra J, Singh M, Palni L and Nandi S (2010) Assessment of genetic fidelity of encapsulated microshoots of Picrorhiza kurrooa. Plant Cell, Tiss. Org. Cult. 78: 1-6.

Nath and Bugagohain (2005) In the present study, the individual effect of 2,4-D and NAA showed a poor response for the induction of embryogenic callus. www.springerlink. com/index/K874XWL11V66175P.pdf

Redenbaugh K, Fujii JA and Slade D (1993) Hydarated coatings for synthetic seeds. In: Redenbaugh K (Ed) Synseeds application of synthetic seeds to crop improvement. CRC Press. Boca Raton. pp. 35-45.

Roy B and Mandal AB (2008) Development of synthetic seeds involving androgenic and pro-embryos in elite indica rice. Ind. J. Biotechnol. 7(4): 515-519.

Shibli R and Ajlouni MM (2000) Somatic embryogenesis in the endemic black iris. Plant Cell Tiss. Org. Cult. 61: 15-21.

Sonia BS, Khan SZ and Hassan L (2010) In vitro regeneration in cole crops. J. Bangladesh Agril. Univ. 8(2): 227-232.

Tabassum B, Nasir IA, Abdul MF, Rehman Z, Latif Z and Husnain T (2010) Viability assessment of in vitro produced synthetic seeds of cucumber. African J. Biotechnol. 9(42): 7026-032.

Yussof AIM, Wafa SNA and Taha RM (2011) Plant Regeneration and synthetic seeds production of Brassica oleracea var. italic. Acta Horticulturae 958: 179-186. 